\title{
Nocardiopsis halophila sp. nov., a New Halophilic Actinomycete Isolated from Soil
}

\author{
AMIRA MAHMOUD AL-TAI ${ }^{1}$ AND JI-SHENG RUAN ${ }^{2 *}$ \\ Department of Soil Microbiology, State Board of Agricultural Research, Ministry of Agriculture, Baghdad, Iraq, ${ }^{1}$ and \\ Institute of Microbiology, Academia Sinica, Beijing 100080, People's Republic of China ${ }^{2}$
}

\begin{abstract}
A new species, Nocardiopsis halophila, is proposed. This species is represented by a single isolate obtained from a saline soil sample in Iraq. This organism grows in both synthetic and organic media containing concentrations of $\mathrm{NaCl}$ up to $20 \%(\mathrm{wt} / \mathrm{vol})$ and is resistant to lysozyme. Whole-cell hydrolysates contain meso-diaminopimelic acid (cell wall type III) and no diagnostic sugars (sugar pattern C). The phospholipid type is type PIII. The predominant menaquinone is $\mathrm{MK}-10\left(\mathrm{H}_{6}, \mathrm{H}_{8}\right)$, and mycolic acids are absent. This organism forms abundant white aerial mycelia and long irregularly branched spore chains that have a zigzag appearance and fragment into spores of various lengths. The substrate mycelia are extensively branched and are rarely fragmented. These properties suggest that this bacterium should be placed in the genus Nocardiopsis. However, this organism differs from all previously described species of the genus Nocardiopsis in its ability to grow in the presence of $20 \%(\mathrm{wt} / \mathrm{vol}) \mathrm{NaCl}$ and also in many other physiological and biochemical characteristics. Thus, we propose that this organism is a new species, Nocardiopsis halophila. Type strain IQ-H3 has been deposited in the Culture Collection of the Institute of Microbiology, Academia Sinica, Beijing, People's Republic of China, as strain A.S.4.1195.
\end{abstract}

The occurrence of actinomycetes in highly saline environments and the tolerance of these organisms to high concentrations of salts have been described by Tresner et al. (23) and Gottlieb (11). Detailed characterizations and chemotaxonomic studies of an extremely halophilic actinomycete, Actinopolyspora halophila, have been carried out by various groups of workers $(5,7,8,13,14)$. From a saline soil in Iraq we isolated an unusual filamentous bacterium which grew best in the presence of high $\mathrm{NaCl}$ concentrations (up to $20 \%$, wt/vol) but also grew in the absence of $\mathrm{NaCl}$. In this paper we describe morphological, physiological, and chemical data which support identification of this isolate (strain IQ-H3 ${ }^{\mathrm{T}}[\mathrm{T}=$ type strain]) as a new species of the genus Nocardiopsis. The name Nocardiopsis halophila sp. nov. is proposed for this organism.

\section{MATERIALS AND METHODS}

Bacterial strain and cultivation. Strain IQ- $\mathrm{H} 3^{\mathrm{T}}$ was originally isolated from a saline soil obtained from Iraq by using a modified complex medium (SGA agar) that contained $20 \%$ (wt/vol) $\mathrm{NaCl}(1)$. This medium contained the following ingredients: $15.0 \mathrm{~g}$ of agar (Difco), $7.5 \mathrm{~g}$ of Casamino Acids (Difco), $10.0 \mathrm{~g}$ of yeast extract (Difco), $20.0 \mathrm{~g}$ of $\mathrm{MgSO}_{4} \cdot 7 \mathrm{H}_{2} \mathrm{O}, 3.0 \mathrm{~g}$ of sodium citrate, $2.0 \mathrm{~g}$ of $\mathrm{KCl}, 200.0 \mathrm{~g}$ of NaCl , and $1,000.0 \mathrm{ml}$ of $\mathrm{H}_{2} \mathrm{O}(20)$. It also contained $1 \mathrm{ml}$ of a trace salt solution per liter. The trace salt solution contained $0.1 \mathrm{~g}$ of $\mathrm{FeSO}_{4} \cdot 7 \mathrm{H}_{2} \mathrm{O}$, $0.1 \mathrm{~g}$ of $\mathrm{ZnSO}_{4} \cdot 7 \mathrm{H}_{2} \mathrm{O}, 0.1 \mathrm{~g}$ of $\mathrm{MnCl}_{2} \cdot 4 \mathrm{H}_{2} \mathrm{O}$, and $100.0 \mathrm{ml}$ of distilled water (21); and the pH was adjusted to 7.5 to 7.6 with a $\mathrm{KOH}$ solution before sterilization. Inoculated plates were incubated at $30^{\circ} \mathrm{C}$ for 10 to 14 days. Stock cultures were maintained on SGA agar slants and kept at $4^{\circ} \mathrm{C}$.

Data for other cultures, including Nocardiopsis dassonvillei DSM $43111^{\mathrm{T}}$, Nocardiopsis alborubida DSM $40465^{\mathrm{T}}$, Nocardiopsis listeri DSM $40297^{\mathrm{T}}$, Nocardiopsis alba subsp. alba DSM 43119, Nocardiopsis alba subsp. prasina DSM 43845 ${ }^{\mathrm{T}}$, and Nocardiopsis lucentensis DSM $44048^{\mathrm{T}}$, were obtained from references 1a, 12, and 24 .

* Corresponding author. Phone: 86-1-2553628. Fax: 86-1-2560912.
Growth characterization. Strain $\mathrm{IQ}-\mathrm{H} 3^{\mathrm{T}}$ was cultivated on SGA agar and Bennett agar media that contained different concentrations of $\mathrm{NaCl}(0,5,10,15,20$, and $25 \%$, wt/vol $)$, on actinomycete isolation agar (Difco), and on glucose-salt agar (6) supplemented with $15 \%$ (wt/vol) $\mathrm{NaCl}$. After 14 to 21 days of incubation at $30^{\circ} \mathrm{C}$, the colors of the substrate mycelium and the aerial mycelium and the production of soluble pigments were determined. The colors were determined by comparison with Color Standards and Color Nomenclature (18).

Growth temperature. The ability of strain IQ- $\mathrm{H} 3^{\mathrm{T}}$ to grow at various temperatures $\left(10,16,25,30,37\right.$, and $\left.42^{\circ} \mathrm{C}\right)$ was determined after 7 to 21 days; SGA and Bennett media supplemented with $15 \%$ (wt/vol) $\mathrm{NaCl}$ were used.

Morphological characterization. Culture morphology was determined with a light microscope. To determine the morphology of the mycelium, the cells were first stained by a previously described method (19). The spore surface was examined by electron microscopy.

Chemical analysis of cells. The organism was grown in $500-\mathrm{ml}$ Erlenmeyer flasks containing $100 \mathrm{ml}$ of modified complex medium (SGA) supplemented with $15 \%$ (wt/vol) $\mathrm{NaCl}$. Inoculated broth cultures ( $3 \%$ inoculum) were grown on a rotary shaker at $200 \mathrm{rpm}$ and $30^{\circ} \mathrm{C}$ for 3 to 4 days. The mycelia were harvested by centrifugation at $4,000 \mathrm{rpm}$ for $10 \mathrm{~min}$ at $4^{\circ} \mathrm{C}$ and washed three times with distilled water. The diaminopimelic acid isomers and sugars present in the whole-cell hydrolysates were determined by the methods of Lechevalier and Lechevalier (15). Menaquinones were extracted and purified by the method of Collins (3) and were identified by high-performance liquid chromatography, using a $\mu$ Bondapak C-18 column and an acetonitrile-isopropanol (3:1, vol/vol) eluent system. Each isoprenolog was detected at $254 \mathrm{~nm}$. Phospholipids were extracted and identified by using the methods of Lechevalier and Lechevalier (15). The mycolic acids present were determined by using the method described by Minnikin et al. (17).

Physiological characterization. Carbon utilization, acid production, degradation of tyrosine, xanthine, esculin, and urea, and resistance to lysozyme were determined by the methods of Berd (2) and Gordon and Barnett (10). Lipase production was 

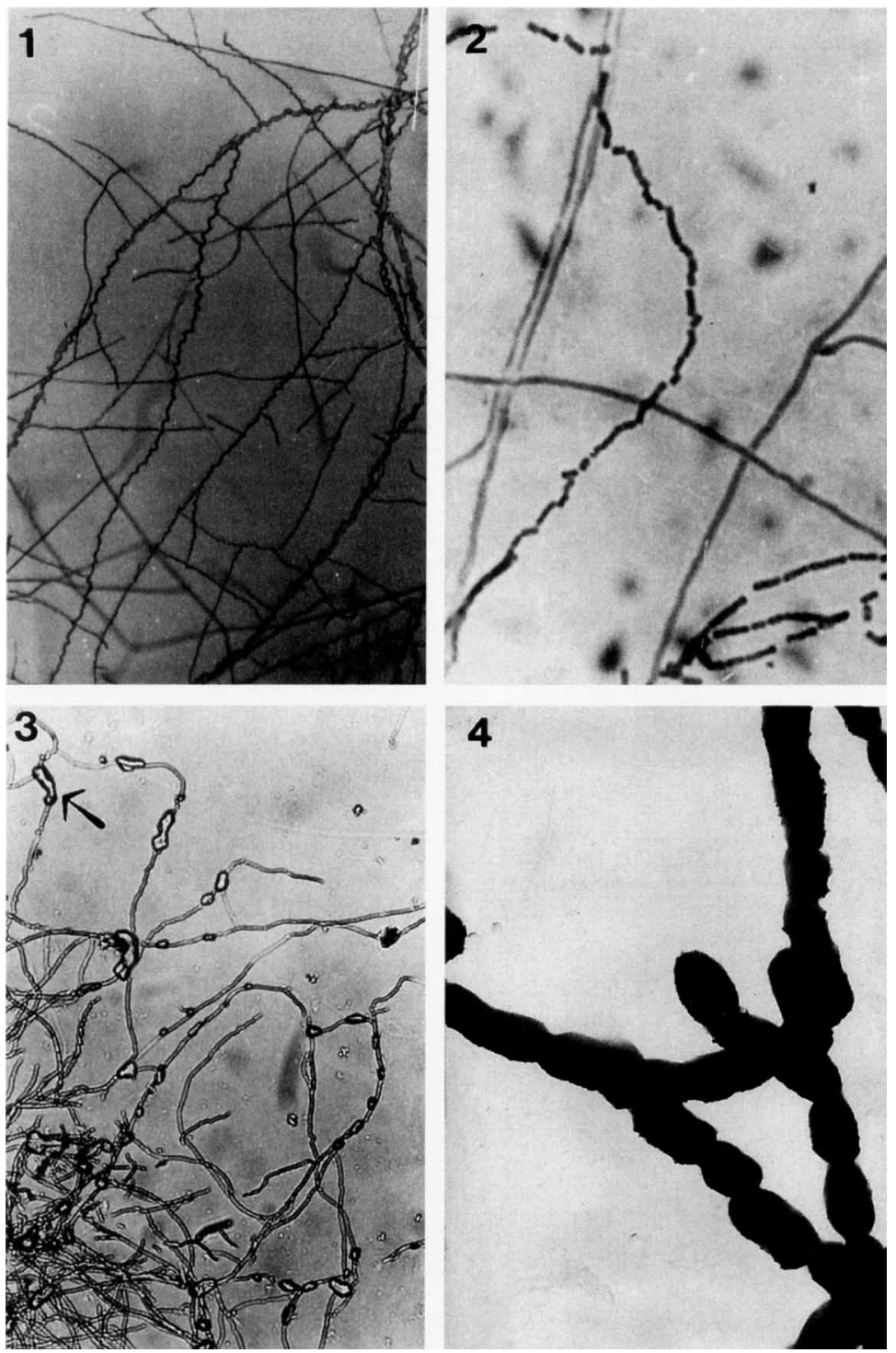

FIG. 1-4. Micrographs of strain IQ-H3 ${ }^{\mathrm{T}}$ grown on SGA agar containing $15 \%$ (wt/vol) $\mathrm{NaCl}$.

FIG. 1. Light micrograph of branched aerial mycelium in an 18-day-old culture, showing long straight and zigzag hyphae. Magnification, $\times 800$.

FIG. 2. Light micrograph of fragmented aerial mycelium in an 18-day-old culture. Magnification, $\times 2,432$.

FIG. 3. Light micrograph of unfragmented substrate mycelium and salt crystals (arrow) in an 18-day-old culture. Magnification, $\times 1,800$.

FIG. 4. Electron micrograph of strain IQ- $\mathrm{H}^{\mathrm{T}}$ spores in a 10 -day-old culture. Magnification, $\times 10,000$.

determined by the method of Gonzalez and Gutierrez (9). Hydrolysis of starch and hydrolysis of cellulose were determined on glucose-salt medium which was supplemented with $0.5 \%$ soluble starch or carboxymethyl cellulose instead of glucose. Amylolytic and cellulolytic activities were determined by the formation of clear zones, using Lugol (4) and Congo red (22) solutions as indicators, respectively. Susceptibility to various antimicrobial compounds was tested by using the impregnated filter paper disc method. Antagonism toward cultures of Escherichia coli IBTC281 and Schizosaccharomyces pombe IBTC18-1-1 was determined by the plug technique. All test media mentioned above were supplemented with $15 \%$ (wt/vol) $\mathrm{NaCl}$. The inoculated plates or liquid media were incubated at 30 or $37^{\circ} \mathrm{C}$. The results were recorded periodically.

\section{RESULTS}

Morphological characteristics. Strain IQ- $\mathrm{H3}^{\mathrm{T}}$ was found to be an aerobic, gram-positive, non-acid-fast, nonmotile organism which formed an extremely well-branched, fine substrate mycelium 0.8 to $1.0 \mu \mathrm{m}$ in diameter. Fragmentation of hyphae rarely occurred either on agar or in liquid media. The long, irregularly branched aerial mycelium (diameter of hyphae, 1 to $1.2 \mu \mathrm{m}$ ) had a zigzag appearance and fragmented into elongated spores of different sizes ( 1 to 1.2 by 2 to $2.5 \mu \mathrm{m}$ ), and the spores had smooth surfaces (Fig. 1 through 4).

Cultural characteristics. The cultural characteristics of strain IQ-H3 ${ }^{\mathrm{T}}$ are summarized in Table 1 . There was abundant growth on SGA and Bennett agar media in the presence of 5 to $15 \%$ (wt/vol) $\mathrm{NaCl}$, and there was fair growth on media 
TABLE 1. Cultural characteristics of strain IQ-H3 ${ }^{\mathrm{T}}$ on different media

\begin{tabular}{|c|c|c|c|c|c|}
\hline \multirow{2}{*}{ Medium } & \multirow{2}{*}{$\begin{array}{c}\mathrm{NaCl} \text { concn } \\
(\%, \text { wt/vol })\end{array}$} & \multirow{2}{*}{ Growth $^{a}$} & \multicolumn{2}{|c|}{ Characteristics of: } & \multirow{2}{*}{$\begin{array}{l}\text { Soluble } \\
\text { pigment }\end{array}$} \\
\hline & & & Substrate mycelium & Aerial mycelium & \\
\hline \multirow[t]{6}{*}{ Modified complex (SGA) } & 0 & + , Wrinkled & Deep hellebore red, leathery & Pale ecru-drab, sparse & None \\
\hline & 5 & +++ , Flat & Hellebore red, leathery & White, abundant & None \\
\hline & 10 & +++ , Flat & Onion skin pink, leathery & White, abundant & None \\
\hline & 15 & +++ , Flat & Cream, leathery & White, abundant & None \\
\hline & 20 & + , Flat & Cream, leathery & White, abundant & None \\
\hline & 25 & - & - & - & - \\
\hline \multirow[t]{6}{*}{ Bennett agar } & 0 & + , Wrinkled & Pale yellow, leathery & White, sparse & None \\
\hline & 5 & +++ , Flat & Margnerite yellow, leathery & White, abundant & None \\
\hline & 10 & +++ , Flat & Coral red, leathery & White, abundant & None \\
\hline & 15 & ++ , Flat & Coral red, leathery & White, abundant & None \\
\hline & 20 & + , Flat & Baryta yellow, leathery & White, sparse & None \\
\hline & 25 & - & - & - & - \\
\hline Actinomycete isolation agar (Difco) & 15 & ++ , Flat & Baryta yellow, leathery & White, sparse & None \\
\hline Glucose-salt & & +++ & Pale ochraceous, salmon & White, abundant & None \\
\hline
\end{tabular}

$a+$, fair; ++ , good; +++ , very good; - , absent.

TABLE 2. Morphological, chemical, and physiological characteristics of strain IQ-H $3^{\mathrm{Ta}}$

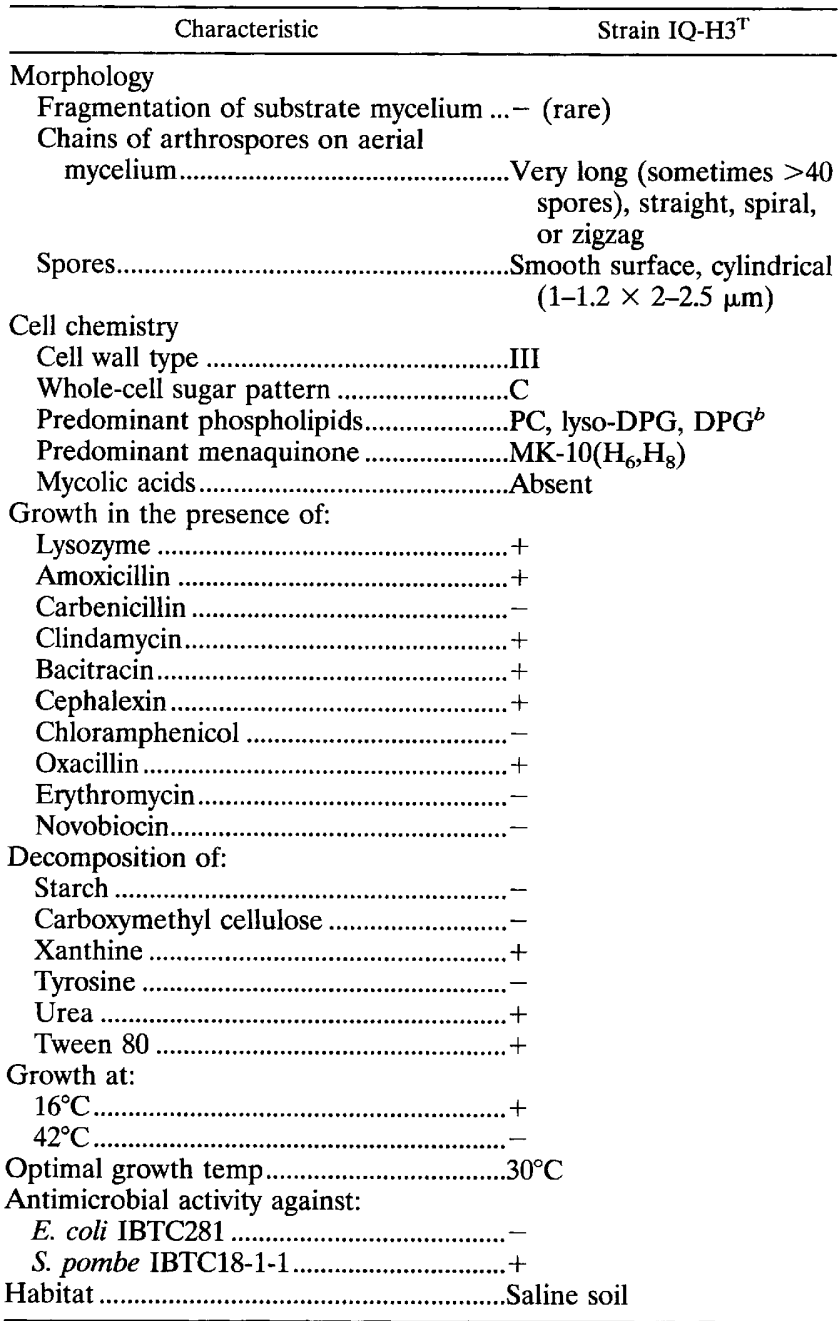

${ }^{a}$ Each test medium contained $15 \%$ (wt/vol) $\mathrm{NaCl}$ - , negative; +, positive.

${ }^{b}$ PC, phosphatidylcholine; DPG, diphosphatidylglycerol. supplemented with $20 \%$ (wt/vol) $\mathrm{NaCl}$. This organism grew on media without $\mathrm{NaCl}$ but grew best when $\mathrm{NaCl}$ was present. No growth occurred in the presence of $25 \%$ (wt/vol) $\mathrm{NaCl}$. Very good growth was observed in glucose-salt medium that contained $15 \%$ (wt/vol) $\mathrm{NaCl}$. The vegetative mycelial pigments ranged from creamy yellow to coral red. The spore mass was white, and there were no diffusible pigments.

Chemical analysis of cells. The cell wall hydrolysate contained only meso-diaminopimelic acid, and the whole-cell sugar pattern was a type C pattern. The organism had a type PIII phospholipid pattern, and the major menaquinone was MK-10 $\left(\mathrm{H}_{6}, \mathrm{H}_{8}\right)$; the minor menaquinone was MK- $9\left(\mathrm{H}_{4}\right)$. Mycolic acid was absent.

Physiological characteristics. The physiological properties of IQ-H3 ${ }^{\mathrm{T}}$ are summarized in Tables 2 and 3. This organism was resistant to lysozyme, amoxicillin, clindamycin, bacitracin, cephalexin, and exacillin. However, it was susceptible to carbenicillin, chloramphenicol, erythromycin, and novobiocin. It was able to decompose or hydrolyze xanthine, urea, and Tween 80 but was not able to degrade carboxymethyl cellulose, starch, and tyrosine. No growth occurred at $42^{\circ} \mathrm{C}$. The optimum growth temperature was $30^{\circ} \mathrm{C}$. Strain IQ- $\mathrm{H} 3^{\mathrm{T}}$ utilized a wide range of carbohydrates as sole carbon sources for growth and produced acids from some of these carbohydrates (Table

TABLE 3. Carbon utilization and acid production by strain IQ-H3 ${ }^{\mathrm{T} a}$

\begin{tabular}{lcc}
\hline \multicolumn{1}{c}{ Carbon source } & Utilization & Acid production \\
\hline Control (no carbon) & - & $(-)$ \\
Arabinose & ++ & $(+)$ \\
Galactose & ++ & $(-)$ \\
Glucose & ++ & $(-)$ \\
Fructose & + & $(+)$ \\
Inositol & + & $(+)$ \\
Maltose & ++ & $(+)$ \\
Mannitol & ++ & $(+)$ \\
Mannose & ++ & $(-)$ \\
Raffinose & + & $(-)$ \\
Rhamnose & + & $(+)$ \\
Ribose & ++ & $(+)$ \\
Sucrose & + & $(-)$ \\
Xylose & ++ & $(+)$ \\
\hline
\end{tabular}

${ }^{a}$ Each test medium contained $15 \%$ (wt/vol) $\mathrm{NaCl}$. -, no growth; + , growth; ++ , good growth; $(+)$, positive; $(-)$, negative. 
TABLE 4. Differential characteristics of strain IQ-H3 ${ }^{\mathrm{T}}$ and strains of related Nocardiopsis species and subspecies ${ }^{a}$

\begin{tabular}{|c|c|c|c|c|c|c|c|}
\hline Characteristic & $\begin{array}{l}\text { Strain } \\
\text { IQ-H3 }^{T}\end{array}$ & $\begin{array}{l}\text { N. lucentensis } \\
\text { DSM } 44048^{\mathrm{T}}\end{array}$ & $\begin{array}{l}\text { N. dassonvillei } \\
\text { DSM } 43111^{\mathrm{T}}\end{array}$ & $\begin{array}{l}\text { N. alborubida } \\
\text { DSM } 40465^{\mathrm{T}}\end{array}$ & $\begin{array}{c}\text { N. listeri } \\
\text { DSM } 40297^{\mathrm{T}}\end{array}$ & $\begin{array}{l}\text { N. alba subsp. alba } \\
\text { DSM } 43119\end{array}$ & $\begin{array}{l}\text { N. alba subsp. prasina } \\
\text { DSM } 43845^{\mathrm{T}}\end{array}$ \\
\hline \multicolumn{8}{|c|}{ Growth in the presence of: } \\
\hline $5 \% \mathrm{NaCl}$ & + & + & + & + & + & + & + \\
\hline $10 \% \mathrm{NaCl}$ & + & + & - & - & - & + & + \\
\hline $15-20 \% \mathrm{NaCl}$ & + & ND & ND & ND & ND & ND & ND \\
\hline Resistance to lysozyme & + & - & - & - & - & - & - \\
\hline \multicolumn{8}{|l|}{ Decomposition of: } \\
\hline Tyrosine & - & + & + & + & + & + & + \\
\hline Xanthine & + & + & + & + & + & + & + \\
\hline Urea & + & - & - & - & - & + & - \\
\hline \multicolumn{8}{|l|}{ Hydrolysis of: } \\
\hline Starch & - & + & ND & + & + & + & + \\
\hline Esculin & - & + & + & + & - & + & - \\
\hline \multicolumn{8}{|l|}{ Acid production from: } \\
\hline Glucose & - & + & + & + & - & + & + \\
\hline Inositol & + & + & - & - & - & - & - \\
\hline Mannitol & + & + & - & + & - & - & + \\
\hline Raffinose & - & + & - & - & - & - & - \\
\hline Rhamnose & + & + & + & + & + & - & - \\
\hline Xylose & + & - & + & + & + & + & + \\
\hline
\end{tabular}

${ }^{a} \mathrm{ND}$, not determined; +, positive; -, negative.

3). It also exhibited antimicrobial activity against $S$. pombe IBTC18-1-1.

\section{DISCUSSION}

On the basis of microbiological properties and chemical composition, including the type of cell wall diaminopimelic acid (type III), the sugar pattern (type C), the phospholipid pattern (type PIII), the predominant species of menaquinone [MK-10 $\left.\left(\mathrm{H}_{6}, \mathrm{H}_{8}\right)\right]$, and the lack of mycolic acids, we concluded that strain IQ-H3 ${ }^{\mathrm{T}}$ should be placed in the genus Nocardiopsis (16). Strain IQ-H3 ${ }^{\mathrm{T}}$ was compared with the descriptions of previously described Nocardiopsis species (Table 4); none of the previously described strains required $\mathrm{NaCl}$ or tolerated an $\mathrm{NaCl}$ concentration of $20 \%(\mathrm{wt} / \mathrm{vol})$. IQ- $\mathrm{H} 3^{\mathrm{T}}$ also differed from the previously described species in many other characteristics, as summarized in Table 4. These differences suggested that strain IQ-H3 $3^{T}$ is probably not a member of a previously described Nocardiopsis species. Therefore, we concluded that this organism is a member of a new species and propose the name Nocardiopsis halophila sp. nov. for it.

Nocardiopsis halophila sp. nov. Nocardiopsis halophila (ha. 10. phi' la. Gr. n. halos, salt; Gr. adj. philos, loving; M.L. fem. adj. halophila, loving salt) is an aerobic, gram-positive, non-acidfast, nonmotile, filamentous actinomycete. It forms a long and extensively branched substrate mycelium. Fragmentation of the substrate mycelium is rarely observed; its color ranges from creamy yellow to coral red. The aerial mycelium is irregularly branched with very long hyphae and zigzag and fragments into elongated spores with smooth surfaces. It does not have distinctive pigmentation. The cell wall type is type III. Sugar pattern C. Phospholipid type PIII. The major menaquinone is MK-10 $\left(\mathrm{H}_{6}, \mathrm{H}_{8}\right)$. No mycolic acids are present. Additional physiological characteristics (Tables 3 and 4) include resistance to lysozyme, amoxicillin, clindamycin, bacitracin, cephalexin, and oxacillin and susceptibility to carbenicillin, chloramphenicol, erythromycin, and novobiocin. Hydrolyzes urea and Tween 80 , but does not degrade carboxymethyl cellulose, starch, xanthine, and tyrosine. Produces acids from the carbon sources maltose, mannitol, xylose, fructose, arabinose, ribose, inositol, and rhamnose. Acids are not produced from glucose, sucrose, galactose, mannose, and raffinose. The optimum growth temperature is $30^{\circ} \mathrm{C}$. Tolerates $\mathrm{NaCl}$ concentrations up to $20 \%$ (wt/vol). Habitat: soil.

\section{ACKNOWLEDGMENTS}

This work was carried out at the Institute of Microbiology, Academia Sinica, Beijing, People's Republic of China, and was supported by grants from The Third World Academy of Sciences, the Chinese Academy of Sciences, and the Natural Sciences Foundation of China.

We thank Shi Yanlin and Liu Zhiheng for their help.

\section{REFERENCES}

1. Al-Tai, A. M. Unpublished data.

1a.Athalye, M., M. Goodfellow, J. Lacey, and R. P. White. 1985. Numerical classification of Actinomadura and Nocardiopsis. Int. J. Syst. Bacteriol. 35:86-88.

2. Berd, D. 1972. Laboratory identification of clinically important aerobic actinomycetes. Appl. Microbiol. 25:665-681.

3. Collins, M. D. 1985. Isoprenoid quinone analyses in bacterial classification and identification. Soc. Appl. Bacteriol. Techn. Ser. 20:267-287.

4. Cowan, S. T. 1974. Cowan and Steel's manual for the identification of medical bacteria, 2nd ed., p. 162. Cambridge University Press, Cambridge.

5. Embley, T. M., A. G. O'Donnell, J. Rostron, and M. Goodfellow. 1988. Chemotaxonomy of cell wall type IV actinomycetes which lack mycolic acids. J. Gen. Microbiol. 134:953-960.

6. Forsyth, M. P., and D. J. Kushner. 1969. Nutrition and distribution of salt response in populations of moderately halophilic bacteria. Can. J. Microbiol. 16:253-261.

7. Gochnauer, M. B., K. G. Johnson, and D. J. Kushner. 1989. Genus Actinopolyspora 1975, p. 2398-2401. In S. T. Williams, M. E. Sharpe, and J. G. Holt (ed.), Bergey's manual of systematic bacteriology, vol. 4. Williams \& Wilkins, Baltimore.

8. Gochnauer, M. B., G. Leppard, P. Komaratat, M. Katers, T. Novitsky, and D. J. Kushner, 1975. Isolation and characterisation of Actinopolyspora halophila, gen. et sp. nov. Can. J. Microbiol. 21:1500-1511.

9. Gonzalez, C., and C. Gutierrez. 1970. Presence of lipase among species of extremely halophilic bacteria. Can. J. Microbiol. 16: $1165-1166$.

10. Gordon, R. E., and D. A. Barnett. 1977. Resistance to rifampin and lysozyme of strains of some species of Mycobacterium and Nocardia as a taxonomic tool. Int. J. Syst. Bacteriol. 27:176-178. 
11. Gottlieb, D. 1973. General considerations and implications of the actinomycetes, p. 1-10. In G. Sykes and F. A. Skinner (ed.), Actinomycetales: characteristics and practical importance. Academic Press, Inc., New York.

12. Grund, E., and R. M. Kroppenstedt. 1990. Chemotaxonomy and numerical taxonomy of the genus Nocardiopsis Meyer 1976. Int. J. Syst. Bacteriol. 40:5-11.

13. Johnson, K. G., P. H. Lanthier, and M. B. Gochnauer. 1986. Studies of two strains of Actinopolyspora halophila, an extremely halophilic actinomycete. Arch. Microbiol. 143:370-378.

14. Kates, M., S. Porter, and D. J. Kushner. 1987. Actinopolyspora halophila does not contain mycolic acids. Can. J. Microbiol. 33:822-823.

15. Lechevalier, M. P., and H. A. Lechevalier. 1980. The chemotaxonomy of actinomycetes, p. 227-291. In A. Dietz and D. W. Thayer (ed.), Actinomycete taxonomy. Special Publication no. 6. Society For Industrial Microbiology, Arlington, Va.

16. Meyer, J. 1989. Genus Nocardiopsis 1976, p. 2562-2569. In S. T. Williams, M. E. Sharpe, and J. G. Holt (ed.), Bergey's manual of systematic bacteriology, vol. 4. Williams \& Wilkins, Baltimore.

17. Minnikin, D. E., I. G. Hutchinson, A. B. Caldicott, and M. Goodfellow. 1980. Thin layer chromatography of methanolysates of mycolic acid-containing bacteria. J. Chromatogr. 188:221-233.

18. Ridgway, R., et al. (ed.). 1912. Color standards and color nomenclature. Curator of the Division of Birds, United States National Museum, Washington, D.C.

19. Ruan, J.-S. 1977. The basis of taxonomy of actinomycetes. The Chinese Academic Press, Beijing.

20. Sehgal, S. N., and N. E. Gibbons. 1960. Effect of some metal ions on the growth of Halobacterium cutirubrum. Can. J. Microbiol. 6:165-169.

21. Shirling, E. B., and D. Gottlieb. 1966. Methods for characterization of Streptomyces species. Int. J. Syst. Bacteriol. 16:313-340.

22. Teather, R. M., and P. J. Wood. 1982. Use of Congo redpolysaccharide interactions in enumeration and characterization of cellulolytic bacteria from the bovine rumen. Appl. Environ. Microbiol. 43:777-780.

23. Tresner, H. D., J. S. Hayes, and E. J. Backus. 1968. Differential tolerance of streptomycetes to sodium chloride as a taxonomic tool. Appl. Microbiol. 16:1134-1136.

24. Yassin, A. F., E. A. Galinski, A. Wohlfarth, K. D. Jahnke, K. P. Schaal, and H. G. Trüper. 1993. A new actinomycete species, Nocardiopsis lucentensis sp. nov. Int. J. Syst. Bacteriol. 43:266-271. 